\title{
Comparison of two serologic methods for the diagnosis of hydatidosis ${ }^{1}$
}

\author{
Héctor M. Arienti, ${ }^{2}$ Susana I. Guignard, ${ }^{3}$ Diego E. Rinaldi, ${ }^{3}$ and \\ Osvaldo C. Elbarcha ${ }^{4}$
}

ABSTRACT The sera of 176 patients with epidemiologic antecedents or radiologic and clinical signs of hydatidosis were tested by counterimmunoelectrophoresis (CIE) and enzyme-linked immunoassay (ELISA). A semipurified antigen from cysts of human origin was used for both techniques. The results were compared with those obtained from complementary radiologic studies and were confirmed by examination of excised cysts.

Biopsy confirmed the diagnosis of hydatidosis in 65 patients (37\%) and revealed the presence of other diseases in the remaining 111 (63\%). Of the original 176 patients, $36(20.4 \%)$ were positive by CIE and $62(35.2 \%)$ by ELISA. Both techniques showed an excellent correlation with postsurgical diagnosis; neither produced any false positives, and the ELISA gave false negative results for only three patients $(4.6 \%)$ with cysts that were infected, infertile, or calcified to some degree. The paper describes standardization of an inexpensive and easy-to-use microELISA.

The infection produced in herbivores and humans by the cestode Echinococcus granulosus, known as hydatidosis, is characterized by the formation of cysts normally located on the liver or lung (1-3) and, less frequently, on the bones, spleen, brain, and other organs $(4,5)$. The weight of the cyst, which depends on the degree of disease development, can range from a few grams to as much as seven or eight kilograms. Clinical manifestations of hydatidosis relate primarily to

\footnotetext{
Published in Spanish in the Boletín de la Oficina Sanitaria Panamericana, Vol. 121, No. 3, 1996, pp. 221-227, with the title "Comparación de dos métodos serológicos para el diagnóstico de hidatidosis."

2 Parasitology Laboratory, Hospital Rawson, Córdoba, Argentina. Mailing address: Bajada Pucará s/n. B ${ }^{\circ}$ Crisol, 5014 Córdoba, Argentina.

3 Parasitology Laboratory, Hospital Rawson, Córdoba, Argentina.

4 Virology Division, Central Laboratory of the
} Province of Córdoba, Córdoba, Argentina. cyst size and location, as symptoms are produced by the mechanical compression of neighboring organs $(6,7)$.

The medical and social importance of hydatidosis arises from the harm that it does to both infected individuals and the community (4). Seventy percent of all recorded cases occur among fully productive adults. Treatment is surgical, and a number of operations are often required to effect a cure.

Among the most serious complications of hydatidosis are bacterial infection of the cyst and consequent formation of an abscess requiring urgent surgical intervention. Another serious complication is rupture of the capsule, which can occur either spontaneously or as a result of trauma or manipulation during surgery. Such rupture may lead to dissemination (secondary hydatidosis) or to hypersensitivity (caused by the massive exposure to antigens) followed by shock and death
$(8,9)$. Rates of mortality from hydatidosis are in the neighborhood of $6 \%(6)$.

The disease evolves slowly over a period of years, normally without compromising the patient's general condition. Accordingly, hydatidosis should be suspected when there are epidemiologic antecedents (such as having lived in an endemic area or in close contact with dogs or sheep) or when there are radiologic and clinical signs. In this regard, while only spontaneous expulsion of parasitic detritus from cutaneous fistulas or the respiratory tract, or microscopic examination of an extirpated cyst, can yield a definitive diagnosis (10), it should be noted that immunologic testing is extremely useful when performed in a timely manner.

Hydatidosis can be investigated serologically using a variety of standardized immunologic techniques (11), and for that purpose all such stan- 
dardized techniques and their variants have already been explored (12-20). However, despite the fact that the disease is endemic in Argentina (21), especially in Córdoba Province, until now only a few research centers in other provinces have attempted to identify techniques capable of diagnosing this ailment with high degrees of sensitivity and specificity.

The principal aim of the study reported here was to demonstrate the diagnostic usefulness of combining two standardized techniques-counterimmunoelectrophoresis (CIEF) and the enzyme-linked immunosorbent assay (ELISA) - employing semipurified hydatid antigen extracted from human cysts. It is hoped that once these techniques have been adopted, it will be possible to establish a referral laboratory for the indirect diagnosis of this disease in the central region of Argentina, where a number of provinces (including Córdoba) currently lack this type of service.

\section{MATERIALS AND METHODS}

\section{Patients and samples}

Our study included all patients with epidemiologic, clinical, or radiologic signs of hydatidosis (22-26) who were referred to the Hospital Rawson in the city of Córdoba during the period 1993-1995 by other public or private hospitals in the province of Córdoba or neighboring provinces. All radiologic images consistent with hydatid cysts and all symptoms consistent with visceral compression were considered suspicious.

All patients with suspected cases received computerized axial tomography, echography, and radiography. In addition, $10 \mathrm{~mL}$ of venous blood was drawn from each patient and used to obtain serum samples that were stored at $-20{ }^{\circ} \mathrm{C}$ prior to processing. The study also tested sera from 50 healthy donors, which served as negative controls, and 41 sera from patients with other parasitoses (such as taeniasis, ascariasis, toxocariasis, enterobiasis, trichuriasis, and uncinariasis) to investigate the possibility of nonspecific reactions. No sera were obtained from patients with cysticercosis, as this type of parasitosis is rare in Argentina.

\section{Sources of antigens}

Hydatid antigens were obtained by processing the liquid content of 12 human cysts extracted surgically, following verification of the absence of contamination with bacteria, red blood cells, or leukocytes, and the presence of viable protoscolices upon microscopic examination (27). The cysts were removed at three hospitals in the city of Córdoba and forwarded immediately to our service facility for study and processing.

In order to obtain a partially purified product, the cyst liquid was subjected to dialysis with 10 parts of distilled water after eliminating particles in suspension. Subsequently, the product of the dialysis was centrifuged and given a second dialysis with 10 parts of phosphate buffered solution (PBS) at $4{ }^{\circ} \mathrm{C}$. Once equilibrium was reached, the liquid was subjected to column chromatography. Protein A bound to sefarose $4 \mathrm{~B}$ (Sigma) was used to eliminate host immunoglobulins; the excluded fraction was then collected and precipitated with $50 \%$ saturated ammonium sulfate to separate the antigenic components from the contaminating serum albumin.

A precipitate obtained by centrifuging was dissolved in one quarter of its original volume of distilled water and subjected to dialysis with PBS until the ammonium sulfate was completely eliminated. The proteins in this product were then quantified (28), and the product was fractionated into $100 \mu \mathrm{L}$ aliquots and lyophilized.

\section{Preparation of antigens}

To detect the presence of host proteins, the hydatid antigen was subjected to immunoelectrophoresis (IEF) with goat antiserum (As) against normal human serum. Also, to determine whether hydatid antigen was present in the liquid thus obtained, an IEF was performed using human serum with anti-hydatid antibody (provided by the Department of Rural Zoonosis in Azul, Province of Buenos Aires). Normal human serum was used as a negative control. In all cases, $10 \mu \mathrm{L}$ of hydatid Ag was used for the IEF and $50 \mu \mathrm{L}$ of As was used for the diffusion.

\section{Counterimmunoelectrophoresis for detecting antibodies}

To conduct the counterimmunoelectrophoresis (CIEF), we used strips of cellulose acetate (Cellogel), washed initially with distilled water and subsequently with electrophoresis buffering solution (Veronal/sodium Veronal, $\mu$ or ionic force $=0.1, \mathrm{pH} 8.8$ ). The strips received $5 \mu \mathrm{L}$ of antigen in the cathode region and $5 \mu \mathrm{L}$ of study serum in the anode region, leaving $1 \mathrm{~cm}$ of separation between the two regions. The electrophoretic run (done at $20 \mathrm{~V} / \mathrm{cm}$ ) lasted for one hour. Before being stained, the strips were then washed three times for 10 minutes with a solution of $5 \%$ sodium citrate and $0.1 \%$ Tween 80 and once for 5 minutes with distilled water. Amido Black was used as a colorant; and a solution of methanol, acetic acid, and water (in a ratio of 40:10:50) was applied as an anticolorant.

\section{Standardization of the ELISA}

The ELISA was conducted on polystyrene microplates with a cellulose acetate base. Each microplate well received $20 \mu \mathrm{L}$ of acetone, which was allowed to react for three minutes before the plates were washed with distilled water and left to dry naturally.

Meanwhile, $0.2 \mathrm{~g}$ (wet weight) of cellulose acetate were dissolved in $10 \mathrm{~mL}$ of acetone, and $20 \mu \mathrm{L}$ of this solution were also placed in each well of the microplates, which were then allowed to dry completely at room temperature. Once the microplates were prepared, $10 \mu \mathrm{L}$ of antigen, pre- 
viously diluted to a concentration of $100 \mathrm{ng}$ of protein per $\mathrm{mL}$ of PBS, were placed in each well. The plates were kept at room temperature until the antigen had been adsorbed into the base, without allowing the base to dry completely.

To test for the presence of antihydatid antibodies, the patient's serum was diluted (the cutoff titer was 1:100) in 3\% PBS with milk. A portion $(10 \mu \mathrm{L})$ of this diluted serum was placed in each microplate well, the microplates then being kept at room temperature until the diluted serum was totally adsorbed onto the base.

After that, six five-minute washings with $0.1 \%$ PBS-Tween 80 were performed. To detect the antibody linked to the antigen, protein A marked with peroxidase (Sigma) was used as a conjugate; $10 \mu \mathrm{L}$ of the optimal dilution of this conjugate were then placed in each well and incubated for 30 minutes at room temperature. Following the washing phase (done like the preceding one) peroxidase activity was revealed by applying 4-chloronaphthol and hydrogen peroxide as an enzymatic substrate.

\section{RESULTS}

The diagnosis of hydatidosis was confirmed in 65 of the 176 study patients by surgical biopsy. Of the remaining 111 patients, 24 had no clinical or radiologic signs of hydatid disease but had been considered possible cases because they had epidemiologic or family histories of hydatidosis. Although the other 87 patients had positive radiologic signs, biopsy revealed that they, like the 24 with negative radiology, had infections other than hydatidosis (Table 1).

\section{Counterimmunoelectrophoresis}

A total of 176 serum samples were processed by CIEF. As shown in Table 2, this technique yielded positive results with sera from $36(55 \%)$ of the 65 patients with biopsy-confirmed hydatidosis, and negative results with sera from the remaining 140 patients. There were no false positive results.

TABLE 1. The disorders diagnosed by biopsy or surgery in the 111 study patients with negative serology for hydatidosis (Córdoba, Argentina, 1993-1995)

\begin{tabular}{lrr}
\hline \multicolumn{1}{c}{ Disorder } & No. & $\%$ \\
\hline Congenital cyst & 33 & 30 \\
Tuberculosis & 28 & 25 \\
Benign neoplasia & 20 & 18 \\
Abscess & 18 & 16 \\
Metastatic cancer & 11 & 10 \\
Hepatic ascariasis & 1 & 1 \\
Total & 111 & 100 \\
\hline
\end{tabular}

\section{ELISA}

Of the 65 patients with confirmed hydatidosis, sera from 62 (95\%) yielded positive results with ELISA while three (5\%) yielded false negative results. Sera from these latter patients, who had cysts that were infertile (devoid of parasitic residue) or calcified, also yielded negative CIEF results.

When the results obtained with the two immunologic techniques are compared (Table 2), it can be seen that 55\% of the patients with biopsy-confirmed hydatidosis had positive CIEF results and $95 \%$ had positive ELISA results, whereas all sera from the 111 patients with other diseases (together with all the control sera) yielded negative results in both tests. Thus, the ELISA showed much greater sensitivity than the CIEF, particularly in patients with extrahepatic cysts. (Table 3 groups the study patients by the location of their cysts and shows the percentages of each group whose sera yielded positive CIEF and ELISA results.)

\section{Antigens}

Immunoelectrophoresis of the 12 lots of antigen prepared from the 12 cysts, as described above, did not indicate the presence of host proteins. When samples from these antigen lots were tested with the control antiserum, a single precipitation band was detected in the cathode region that coincided with the arc 5 band obtained when using goat antigen as a control (Pasteur Institute).

When the protein concentration in the samples from the various lots was adjusted to $100 \mathrm{ng} / \mathrm{mL}$, similar results were obtained in all cases.

\section{DISCUSSION}

The patients tested yielded results that varied significantly, depending on the type of test and, to an extent, the location and state of the cyst. The CIEF proved to be less sensitive than the ELISA in patients with cysts outside the liver-in lungs, bone, kidney, etc.-where a powerful antigen stimulus is not normally produced. However, the CIEF did yield a single band of precipitation that was immunologically identical to that obtained with

TABLE 2. Percentages of the 176 study patients with and without surgical or biopsy diagnosis of hydatidosis or positive radiology yielding positive or negative results by CIEF and ELISA (Córdoba, Argentina, 1993-1995)

\begin{tabular}{|c|c|c|c|c|c|}
\hline \multirow{2}{*}{$\begin{array}{l}\text { Surgical biopsy results } \\
\text { for hydatidosis }\end{array}$} & \multirow{2}{*}{$\begin{array}{l}\text { Total No. } \\
\text { of patients }\end{array}$} & \multicolumn{2}{|c|}{$\begin{array}{l}\text { CIEF results } \\
(\%)\end{array}$} & \multicolumn{2}{|c|}{$\begin{array}{c}\text { ELISA results } \\
(\%)\end{array}$} \\
\hline & & - & + & - & + \\
\hline Positive & 65 & 45 & 55 & 5 & 95 \\
\hline \multicolumn{6}{|l|}{ Negative: } \\
\hline with positive radiology & 87 & 100 & 0 & 100 & 0 \\
\hline with negative radiology & 24 & 100 & 0 & 100 & 0 \\
\hline Total & 176 & 80 & 20 & 65 & 35 \\
\hline
\end{tabular}


TABLE 3. Percentages of the patients with confirmed hydatidosis who had hydatid cysts at each of the indicated locations, showing the percentages of each group yielding positive serologic results by CIEF and ELISA

\begin{tabular}{lccc}
\hline $\begin{array}{c}\text { Cyst } \\
\text { location }\end{array}$ & $\begin{array}{c}\text { \% of all } 65 \text { patients } \\
\text { with hydatidosis }\end{array}$ & CIEF-positive (\%) & ELISA-positive (\%) \\
\hline Liver & 59 & 68 & 92 \\
Lung & 22 & 57 & 93 \\
Spleen & 9 & 17 & 100 \\
Bone & 3 & 0 & 100 \\
Abdomen & 3 & 50 & 100 \\
Other & 5 & 0 & 100 \\
Total & 100 & & \\
\hline
\end{tabular}

goat antigen 5. Thus, this test's high degree of specificity justifies its use.

The results obtained in the cases testing positively by CIEF were clearly discernible. The incorporation of the tensioactive agent into the washing solution eliminated nonspecific staining almost entirely, thus facilitating reading of the results.

Standardization of the microELISA was directed at increasing sensitivity and substantially reducing costs. The use of $10 \mu \mathrm{L}$ samples made it possible to shorten incubation times and achieve greater efficiency in the washing stages.

The use of cellulose acetate was directed at making full use of the antigen placed in the well and determining the exact quantity deposited on the base. It also made it possible to eliminate residual antigen after the test in order to reuse the microplates.
By combining both techniques we found it possible to process a large number of samples and obtain extremely reliable results in only two hours. The ELISA's high degree of sensitivity was demonstrated by the low percentage of false negative results, which were only obtained with sera from three patients with cysts that were either partially or totally calcified or devoid of parasitic residue. The test's high degree of specificity was affirmed by the absence of positive reactions in patients with other parasitoses.

In this study, a correct serologic diagnosis was obtained for $55 \%$ of the patients with hydatidosis using the CIEF and for $95 \%$ using the ELISA; these results demonstrate the relative sensitivity of each method. As a result of its high sensitivity, the ELISA described here can be used to deter- mine the antibody titers of candidates for surgery and in this way assess the efficacy of surgery.

When antigen extracted from viable human cysts is used, it must be purified in order to eliminate contaminating immunoglobulins that may produce false positive results. Nevertheless, the use of this antigen is recommended because its high parasite protein content provides a margin for loss through manipulation in the various stages of processing, and so the loss of antigen that normally occurs does not affect the final preparation's quality. In addition, the high incidence of hydatidosis in our geographic area causes viable cysts to be widely available.

Both techniques have advantages. The ELISA is cheap and highly sensitive. Though other authors have reported less encouraging results (2), we found it to be highly specific (no false positive results were recorded), yielding a degree of specificity similar to that of the CIEF. The difference between these results and those reported elsewhere could have resulted from the source of antigen used and/or the purification methods employed. Both the CIEF and the ELISA are rapid techniques that make it possible to process a large number of samples simultaneously and that do not require highly trained technical personnel. Accordingly, we conclude that in our geographic area these techniques provide reliable and adequate tools for use in diagnosing human hydatidosis.

\section{REFERENCES}

1. Eltahir M, Omojola M, Malatani T, Alsahigh A, Ogunbiyl O. Hydatid disease of the liver: evaluation of ultrasound and computer tomography. Br J Radiol 1992;65:390-392.

2. Gouliamos A, Kalovidouris A, Papailiou J, Vlahos L, Papaviasiliou C. CT appearance of pulmonary hydatid disease. Chest 1991;100: 1578-1581.

3. Schaefer J, Khan M. Echinococcosis (hydatid disease): lessons from experience with 59 patients. Rev Infect Dis 1990;13:243-247.
4. Sapunar J. Hidatidosis. In: Atías A, ed. Parasitología clínica. 3rd ed. Santiago: Mediterráneo; 1992:341-353.

5. Stoianov G. Rare localizations of echinococcosis. Khirurgiia 1993;46:10-11.

6. García LS, Bruckner DA. Diagnostic medical parasitology. 2nd ed. Washington, DC: American Society for Microbiology; 1993:401-402.

7. Varela Díaz V, Guarnera E, Marchevsky NN, Rapaport L, Conesa H, Espindola S. Review of hospital cases for the assessment of hydatido- sis as a health problem in the Argentine Province of Chubut. Z Parasitenkd 1983;59: 507-515.

8. Duncan G, Tooke S. Echinococcus infestation of the biceps brachii. Clin Orthop Relat Res 1990;261:247-250.

9. Uriarte C, Pomares N, Martin M, Conde A, Alonso N, Bueno M. Splenic hydatidosis. Am J Trop Med Hyg 1991;44:420-423.

10. Varela Díaz V, Guarnera E, Coltorti E. Ventajas y limitaciones de los métodos inmunológi- 
cos y de detección por imágenes para el diagnóstico de la hidatidosis. Bol Oficina Sanit Panam 1986;100:369-383.

11. Kagan IG. Serodiagnóstico de enfermedades parasitarias. In: Rose N, Friedman H, eds. El laboratorio en inmunología clínica. 2nd ed. Panamericana; 1984;652-653.

12. Barbierri M, Sterla S, Battistoni J, Nieto A. High performance latex reagent for hydatid serology using Echinococcus granulosus lipoprotein antigen fraction purified from cyst fluid in one step. Int J Parasitol 1993;23: 565-572.

13. Biffin A, Jones M, Palmer S. Human hydatid disease: evaluation of an ELISA for diagnosis, population screening and monitoring of control programmes. J Med Microbiol 1993;39: 48-52.

14. Capron A, Yarzabal L, Vernes A, Fruit G. Le diagnostique immunologique de l'echinococcose humaine. Pathol Biol 1970;18:357-365.

15. Coltorti E, Varela Díaz V. Modification of the immunoelectrophoresis test for the immunodiagnosis of hydatidosis. J Parasitol 1975;61: 155-156.

16. Kanwar J, Kaushik S, Sawhney I, Kamboj M, Mehta S, Vinayak V. Specific antibodies in serum of patients with hydatidosis recognized by immunoblotting. I Med Microbiol 1992;36:46-51.
17. Liu D, Lightowlers M, Richard M. Evaluation of a monoclonal antibody-based competition ELISA for the diagnosis of human hydatidosis. Parasitology 1992;104:357-361.

18. Shariff M, Parija S. Co-agglutination (Co-A) test for circulating antigen in hydatid disease. J Med Microbiol 1993;38:391-394.

19. Varela Díaz V, Guisantes J, Ricardes M, Yarzabal L, Coltorti E. Evaluation of whole and purified hydatid fluid antigens in the diagnosis of human hydatidosis by the immunoelectrophoresis test. Am J Trop Med Hyg 1975;24: 298-303.

20. Verastegui M, Moro P, Guevara A, Rodríguez T, Miranda E, Gilman R. Enzyme-linked immunoelectrotransfer blot test for diagnosis of human hydatid disease. J Clin Microbiol 1992;30:1557-1561.

21. Kremer A. Hidatidosis humana. In: Cámera MI, Romani A, Madoery C, Farías J, eds. Avances en medicina. Vol II: XIX Jornadas Nacionales Interresidenciales de Clínica Médica, 23 a 27 de noviembre de 1992. pp 155-164.

22. De Cock K, Calder J. Ultrasonic diagnosis of abdominal disease in Kenya. Trans $R$ Soc Trop Med Hyg 1981;75:632-636.

23. Grabbe E, Kern P, Heller M. Human echinococcosis: diagnostic value of computed tomography. Tropenmed Parasitol 1981;32: 35-38.
24. Guarnera E, Varela Díaz V. Limitaciones de la tomografía axial computada en la localización de quistes hidatídicos abdominales en pacientes con confirmación inmunodiagnóstica. Rev Inst Med Trop Sao Paulo 1984;26: 301-306.

25. Guarnera E, Varela Díaz V. Immunodiagnosis of pulmonary hydatid disease in a patient with negative radiologic and scintillographic findings. Trans $R$ Soc Trop Med Hyg 1985;79: 149-150.

26. Moguillansky P. Radiología de la echinococcosis hidatídica hepática. Arch Int Hid 1966;22: 461-481.

27. Casado N, Rodríguez-Caabeiro F, HernándezRodríguez S. In vitro survival of Echinococcus granulosus protoscolices, at $4{ }^{\circ} \mathrm{C}$ and $37^{\circ} \mathrm{C} . \mathrm{Z}$ Parasitenkd 1986;72:273-278.

28. Bradford M. A rapid and sensitive method for the quantitation of microgram quantities of proteins utilizing the principle of protein-dye binding. Anal Biochem 1976;72:249-254.

Manuscript received 2 June 1995. Revised version accepted for publication on 20 March 1996.

RESUMEN El suero de 176 pacientes con antecedentes epidemiológicos o signos radiológicos y clínicos de hidatidosis fue sometido a contrainmunoelectroforesis (CIEF) e inmunoensayo enzimático (ELISA), utilizándose para ambas técnicas un antígeno semipurificado obtenido de los quistes de pacientes. Los resultados se compararon con los obtenidos por estudios radiológicos complementarios y se corroboraron mediante el examen de los quistes resecados.

La biopsia confirmó el diagnóstico de hidatidosis en 65 (37\%) pacientes y reveló la presencia de otras enfermedades en los 111 (63\%) pacientes restantes. De los 176 pacientes estudiados, $36(20,4 \%)$ tuvieron resultados positivos en la CIEF y $62(35,2 \%)$ en el ELISA. Los resultados de ambas técnicas mostraron una excelente correlación con el diagnóstico posquirúrgico, ya que no hubo un solo resultado positivo falso y el ELISA produjo resultados negativos falsos en tres $(4,6 \%)$ pacientes con quistes infectados, infértiles o con algún grado de calcificación. Por último se describe la estandarización de un microELISA fácil de usar y barato. 